\title{
Priming Europe: Media Effects on Loyalty, Voice and Exit in European Parliament Elections
}

\author{
Susan Banducci \\ University of Exeter \\ Heiko Giebler \\ WZB, Berlin \\ Sylvia Kritzinger \\ University of Vienna \\ Georgios Xezonakis \\ University of Gothenburg
}

\begin{abstract}
:
Parties in government face a decline in EP elections after experiencing a surge in votes to win the national election. This occurs because voters are more inclined to give voice to their dissatisfaction with current government performance by voting for the opposition or exiting because less is at stake in second-order elections. These elections negatively affect the electoral fortunes of governing parties as voters opt to punish poorly performing national governments in EP elections. Meanwhile, greater reliance on the EU issue dimension in vote choice models is taken as evidence for the increasing Europeanisation of EP elections. We examine the role of the media in making the EU issue dimension salient in such a way that government parties may benefit electorally from this increased saliency. To examine whether visibility of government party actors in media coverage increases loyalty for the governing parties either directly or via priming the EU issues for voters, we combine survey data from the 2009 European Election Studies (EES) with data on news coverage of those elections that links the governing party to the EU issue. We show that where the government is visible in EU news coverage, EU issue voting tends to increase loyalty while decreasing the probability to vote for the opposition and thus improves the electoral prospects for governing parties. This is even more the case if the issue is primed by negative campaign coverage.
\end{abstract}


$\underline{\text { Keywords: }}$

News media, EU coverage, EU issue voting, voting calculus, governing party 


\section{$\underline{\text { Introduction }}$}

Research on the nexus between transnational and national politics, in this case between attitudes towards European integration and individual electoral behaviour in EU-member states, has mostly produced 'negative' results. 'Europe' is rarely a relevant issue - not in national elections or even in European Parliament elections (de Vreese et al, 2006; Schuck et al, 2011). This holds both for the behaviour of elites and the behaviour of the voters. Hence, EP elections are commonly described as second-order national elections (Reif and Schmitt, 1980; Marsh, 1998), with national issues dominating the electoral campaign and parties in government facing electoral losses. Voters in the second-order EP elections have the possibility to express their dissatisfaction with national politics by voting for opposition parties, also because less is at stake (Hix and Marsh, 2007). Recent evidence does not, overall, challenge this claim but has opened the window for some 'European' potential. The 'sleeping giant' hypothesis (van der Eijk and Franklin, 2004), the work of Kriesi et al (2006, 2008), and more recently of de Vries (2007) and Hobolt et al (2009) suggest that the European issue is becoming relevant for electoral behaviour and, as a consequence, for electoral outcomes both at national and EP elections.

Following and extending this line of research, we investigate whether and how the diffusion of the European dimension into the electoral arena reduces the competitive disadvantages of governing parties at EP elections, focusing on the role the news media play in potentially transforming EP elections into first-order affairs. An increased focus on EU issues may be advantageous for government parties as they enjoy a better reputation regarding EU issues and are ascribed higher competence concerning them, compared to opposition parties, in the sense that they can deliver on the EU issue. Furthermore, the moment EU issues gain more media attention and thus become more salient in the mind of citizens, governments may suffer less from protest voting caused by national politics, which has been induced by EP electoral campaigns in the past. The likelihood of expressing dissatisfaction with national politics by punishing government parties in EP elections decreases the more citizens base evaluations of national political actors on EU level issues. Therefore, a decrease in the losses of governing parties in EP elections could follow in the case EP elections no longer qualify as second-order elections and show increased independence from heuristics based on the national political 
context. In this paper, we examine how voters who have supported a government party in the previous national election are affected by the news media in their voting decisions at EP elections.

To test the above claim we make use of an extensive data collection effort that took place right before and after the EP elections of 2009. More than just a straightforward voter survey, the European Election Study of 2009 also gathered data on media content during the three weeks of the campaign in all of the then 27 member states. Here we combine the Voter Study and data drawn from the Media Content Analysis to provide a test of whether news media reporting on European integration can improve the fate of government parties in second-order elections. Our findings suggest that news media tend to condition electoral behaviour in such a way that as media coverage of EU related issues linked to government parties increases, these issues tend to matter more for individual voting decisions, and the competitive disadvantage of parties in government in EP elections is reduced.

We proceed as follows: we first review the literature on European issue voting as well as media priming and set out our theoretical and empirical expectations. A concise discussion of the data, methods and the results of our models is presented in the second section. We conclude the paper with a discussion of our findings and some implications for European issue voting and the nature of EP elections.

\section{Information, Media Priming, and Government Evaluations}

European parliamentary elections have been characterized as second-order national elections (Reif and Schmitt, 1980). This implies three particular characteristics of EP election campaigns: low campaign intensity; national, not European, issues on the agenda; and electoral defeats of government parties. First, the second-order theory of EP elections hypothesises that the turnout difference between EU and national elections is due to the lack of mobilization in EU elections. Because "less is at stake" in EU elections, parties are less likely to mobilize voters, the media do not cover the campaigns and turnout will be lower than in national campaigns. Second, the issue agenda during European election campaigns is dominated by national issues and not European ones. 
European issues are not a relevant category in the citizens' party choices. And third, government parties lose vote shares as the EP elections are about national issues and voters have the possibility to express their dissatisfaction with the performance of governing parties.

These government losses are at the core of our analysis. Similar in result to what Campbell (1960) called 'surge and decline' in the US context, parties in government tend to suffer in second-order elections by losing a significant number of voters who supported them in the last first-order election (Hix and Marsh, 2011: 8). Deviant behaviour in EP elections can come in two shapes: Borrowing terms from Hirschman (1970) - and similar to a study by Weber (2011) but with a less complex adaption - we can distinguish former supporters who express dissatisfaction through 'voice', i.e. by vote-switching to opposition parties, or those who express dissatisfaction by exiting the electoral process (i.e. abstaining). The third option is showing loyalty, which is represented by voting again for the previously endorsed party in government. Regarding electoral competition, voice is the most harmful option for ruling parties while the harmfulness of exit depends more on the overall mobilization levels. Differentiating between both forms of disloyalty does not only help us to determine the harmfulness, it also speaks to more refined perspectives on second-order elections located on the microlevel which link turnout and party choice to determine and explain vote share differences (e.g., Rohrschneider and Clark, 2008; Weber, 2011; Giebler, 2014; Giebler and Wagner, 2015; Boomgaarden et al, 2016).

If it is true, as many studies suggest, that opting for exit or voice becomes more viable in a second-order context, we would expect comparatively more loyalty in EP elections as soon as they become less dependent on the national political arena. Waking the 'sleeping giant' - increasing the relevance of EU issues for electoral behaviour - is one way to diminish the second-orderness of EP elections. While Mair (2000) and others (see e.g., Krouwel, 2004) have suggested little impact of Europe on citizens' electoral behaviour, there is recent evidence of some electoral Europeanisation. ${ }^{1}$ European issues are gaining in importance in the formation of voter preferences. The influence of Europe on voting

\footnotetext{
${ }^{1}$ On Europeanisation in general see e.g. Hooghe and Marks, 2009.
} 
behaviour has been labelled as "EU issue voting", meaning preferences on European integration and closeness to political parties on this issue structure vote choice. A small group of studies has presented empirical evidence in support of the EU issue voting hypothesis (Evans, 1998, 2002; Gabel, 2000; Tillman, 2004; de Vries, 2007; Hobolt et al, 2009). ${ }^{2}$ EU issue voting is dependent on the political context and it is found in cases where the issue is more salient and where there is partisan conflict over European integration due to coalitional and electoral incentives for parties to emphasise this issue (de Vries, 2007; Hooghe and Marks, 2009; de Vries et al, 2011; Green-Pedersen, 2012).

Our interest in this paper is how higher EU saliency in the news media translates into EU issue voting for government parties at EP elections. In general, most political information is transferred via news media (e.g., Delli Carpini, 2004). News media are expected to exert particular influence once they deal with issues that are not directly connected with citizens' daily experiences, and voters can only learn about from the news media (Page and Shapiro, 1992). These considerations apply to EP elections and EU issues. News media are thus one of the main actors responsible for raising awareness and saliency of Europe in general and of EP elections in particular, and for transmitting evaluations on Europe. As Semetko and de Vreese state, news media provide "cues for citizens' perception of the EU" (2004: 34).

News media, however, dedicate varying degrees of salience to issues and actors. This applies also to the EU issue, which can be presented in connection with different political actors by the news media. Given the established patterns of news coverage by the media, governing parties have greater possibilities of being linked to EU issues as they generally enjoy higher degrees of media attention and can, to a larger extent, display their policy actions (e.g., Norpoth, 1992; Bawn and Somer-Topcu, 2012). Furthermore, as Paper 2 (part of this special issue) discusses, not all parties are considered equally competent on all issues, and parties which the media frame as competent on an issue might benefit from it, especially if that particular issue becomes salient in the election. As a result, that party should have a particular competitive advantage.

\footnotetext{
${ }^{2}$ Specific EU-level policies such as policies on the monetary union have also been found to influence voting behaviour in national elections (Scheve, 1999).
} 
We apply this reasoning to the issue of European integration and argue that if the EU issue becomes more salient, the government parties should have a competitive advantage. As they represent the country's interest on the European level, the competence framing should work to their advantage. As Hix and Marsh indeed state: "[...] if the election is mainly about Europe rather than national concerns [...] we would not expect government parties to lose more votes than opposition [or extreme] parties" (2007: 498). Hence, linking that citizens obtain information from news media to the government bias in terms of media coverage and to the incumbent parties' competitive advantage on EU issues, an increase in EU messages might be most effective for governing parties. Following the second-order literature, we argue that the losses government parties experience at EP elections are likely to decrease, the more information about the European issue linked to government parties is available in EP electoral campaigns. In other words, governments will lose fewer votes, both in terms of exit (abstention) and voice (vote-switching to the opposition). This leads to our baseline visibility hypothesis:

Hypothesis 1: Overall, greater visibility of governing parties in news media coverage on Europe increases the probability of staying loyal by voting again for the governing party/governing coalition in EP elections.

Citizens respond to the wider information environment in terms of updating information on the placement of party positions on European integration (Adams et al, 2011; Banducci et al, 2015). Electoral outcomes can then depend on the distribution of preferences on EU issues, as citizens' voting calculus might be primed by the saliency on this new issue. Indeed, Ferrara and Weishaupt (2004) have argued that parties gaining salience on EU issues can increase their vote share in EP elections. These findings suggest that if the EU issue is being primed for voters, it might affect voting behaviour. Evidence of media priming would be present when, for example, the news media's attention leads to that issue being weighted more heavily in evaluations of party leaders or political actors. In general, priming effects, based on accessibility models of information processing, occur when citizens change the basis of political judgements in 
such a way that some criteria gain greater prominence in the judgment (e.g., Iyengar and Kinder, 1987; Iyengar, 1990). ${ }^{3}$

Hitherto, the second-order literature suggests that given the low level of actual information on the EU, evaluations of the governing parties on national issues drive electoral behaviour in EP election. As information increases, for one, evaluations of EU issues might become more important in determining voters' electoral decisions, for another, voters use EP elections to a lesser degree to express their dissatisfaction with governing parties. In other words, there will be less protest voting against governing parties, and more EU issue voting in favour of incumbents. Hence, in a second step, we explore whether the news media EU coverage can prime citizens' attitudes towards the European issue in such a way as to elevate its saliency in the voting calculus, benefitting voting decisions in favour of government parties as the dominance of national issues is reduced. ${ }^{4}$ Based on the EU issue voting and the priming literature, we overall expect that when European issues are featured more prominently in the news, the proximity of the respondent to the party on European integration will be more influential in predicting the vote choice. We argue that where the governing parties are salient in EU related coverage, the EU issue carries more weight in an individual's vote calculus. Therefore, we explore the priming hypothesis:

Hypothesis 2: The more the EU issue is linked to parties in government in the news media EU coverage, the greater the influence of citizens' proximity on the EU dimension will be in determining citizens' loyal vote.

\footnotetext{
${ }^{3}$ Price and Tewksbury (1997: 197) characterise the process of media priming in the following way: "First, a media message renders one or another construct applicable, and that construct - say unemployment - is activated. By virtue of its activation, and in direct proportion to the recency and frequency of its activation, that construct remains temporarily accessible. [...] Subsequently, when a person is called on to evaluate the performance of the president, unemployment is likely to be evaluated." (1997: 197)

${ }^{4}$ We note here two caveats stemming from previous research on priming. First, we observe that it is difficult to distinguish between priming and learning. Evidence that can be interpreted as priming might also be voters learning the positions of their preferred parties and adopting similar positions (Lenz, 2009, 2012). Tesler (2014) provides evidence that priming better explains the process of linking salient issues to preferences for long held predispositions, while learning about party positions explains how issues salient in a campaign can influence preferences for newer issues. While it is not our intent to disentangle whether projection or priming is at work, we note the possibility that where government parties are willing to stake out their EU position in an election campaign (and hence gain greater news media coverage on that position), voters may be learning about that position and adopting similar positions.
} 
In terms of both the direct and priming effects of news media, we consider valence. The evaluative tone of the coverage about government actors is expected to influence the effect of the media coverage (Sheafer, 2007). In agenda setting studies, a positive tone reduces the saliency attached to an issue (Schoenbach and Semetko, 1992). This finding is consistent with more recent research suggesting that negative information is better at capturing attention (Mutz, 1998; Marcus et al, 2000). Hence, we formulate the following valence hypothesis:

Hypothesis 3: Where the tone of EU coverage linked to governing parties is negative, the direct and the priming impact of visibility of government actors on staying loyal with governing parties in EP elections will be greater.

\section{Data and Methods}

In this section, we present our empirical measures and methods of capturing the visibility of government actors in stories about the EU. To test our hypotheses, we rely on data from the European Election Study 2009 (PIREDEU). ${ }^{5}$ The post-election survey of 2009 was carried out immediately after the election in June 2009. A media content analysis based on campaign news coverage leading up to the EP election is used to provide a direct measure of the amount of electorally relevant information. Over a three-week period, the content analysis was carried out on a sample of national news media coverage in all 27 EU member states (comprised of broadsheets, tabloids, public and commercial broadcasts). ${ }^{6}$ The overall television sample consists of $58 \mathrm{TV}$ networks and the overall newspaper sample includes 84 different newspapers. ${ }^{7}$

As we are interested in exploring the determinants of reducing the competitive disadvantage of governing parties in second-order EP election, we measure vote choice for incumbents in EP elections relative to voters' electoral decision in the previous

\footnotetext{
${ }^{5}$ Data collection for post-election survey and media content analysis was carried out under the auspices of 'Providing an Infrastructure for Research on Electoral Democracy in the European Union' (PIREDEU): van Egmond et al, 2013; Schuck et al, 2010.

${ }^{6}$ We focus on national television and newspapers because these media are consistently listed as the most important sources of information about the EU for citizens in Europe (Eurobarometer 54-62).

${ }^{7}$ The list of outlets as well as more information on the coding can be found in Schuck et al, 2011.
} 
national election. Following Hirschman's framework (1970), we use the recall question to establish whether a voter has remained loyal to the previously endorsed governing party, whether she voiced support for an opposition party, or has exited the political system by abstaining. ${ }^{8}$ Respondents who voted for an opposition party or abstained in the previous national election were excluded from the analyses.

The distribution of voters for incumbents in the previous national elections in the EP election 2009 is as follows. While a majority of government voters (57 per cent) also supported the incumbent in the EP election, 26 per cent of former government voters abstained and 17 per cent voiced support for an opposition party. ${ }^{9}$

The three core variables to test our hypotheses are the EU integration issue proximity, the governments' media hits - stories about the EU referring to the government or parties in government - and the tone of these media hits. Proximity on EU integration is measured in the common way using the respondents' self-positioning as well as the ascribed party positions on 11-point scales. We calculated the proximity of a respondent's position to the government's position. The latter is defined as the weighted mean of all parties in government with weighting being done on the basis of vote shares at the last national election.

To measure the government specific information available in the news environments, we focus on news stories from the media content analysis that mention the EU. Within each story, we code whether the parties in government, parties in opposition or other actors appear in the story. ${ }^{10}$ Our measure of the information available linked to the government in news stories is the proportion of all news stories mentioning the EU and the

\footnotetext{
${ }^{8}$ Though we are aware that recall questions are plagued by considerable errors (e.g., van der Eijk and Niemöller, 2008; Waldahl and Aardal, 2000), recent findings have indicated that measurement error in recall data has a limited impact on the validity of research findings (Dassonneville and Hooghe, 2016).

${ }^{9}$ After applying listwise deletion regarding all variables used in this study, the proportions differ slightly: 60 per cent stay loyal, 22 per cent exit (abstention) and 17 per cent give voice (vote for the opposition). The sample size drops from 9,700 to 5,934 respondents. However, these differences are unsystematic regarding the variables used in our analysis and, hence, should not affect our results.

${ }^{10}$ Detailed information on coder training, coding procedures and related issues can be found in Schuck et al (2010). Inter-coder reliability is very high for the first step - identifying EU stories (Krippendorff's Alpha $=0.8$ ). It is much lower for the assignment of actor codes (0.45). However, taking into account the large number of different actors - several thousand codes were assigned - we see this as an acceptable value. Moreover, we collapse the data by only differentiating between government and opposition actors which makes any coding error within one of the groups unproblematic for our analysis.
} 
government or parties in government of all stories on EU issues in a country. For example, if there were ten EU news stories for the day and two mentioned government party actors, our indicator of visibility is 20 per cent. In the original coding process, each news story was coded on a five-point scale representing negative, negative as well as positive, or a positive tone towards the actor. ${ }^{11} \mathrm{We}$ calculated the average tone of all messages referring to the government and the EU. ${ }^{12}$

Several other factors should influence the probability to vote for any of the parties in government in an EP election. Hence, we estimate a model where we include several control variables from the voter survey. We use a measure of party identification (measuring whether a respondent identifies with any of the parties in government), the proximity on the left-right dimension (calculated in the same way as the EU integration issue proximity), a binary measure on whether the respondent approves of the government's record and a categorical measure on how the national economy has developed in the last 12 months (got worse, stayed the same and got better - the first constituting the base category in all models). Finally, following the argument about the role of the electoral cycle (Reif and Schmitt, 1980) which predicts that governing parties will lose the most votes in mid-term, we include a respective measure as well. All continuous independent variables have been standardized by dividing them by two standard deviations to make effect size comparable between all independent variables in the models (see Gelman, 2008). ${ }^{13}$

To predict electoral behaviour in one of the three vote choice categories we run a multinomial logit model. To estimate multinomial logit models in a multi-level setup, we run a Generalized Structural Equation Model (GSEM). Such a hierarchical structure becomes necessary to estimate efficient standard errors and to control for correlated error terms while at the same time providing more information than a simple regression with

\footnotetext{
${ }^{11}$ A significant proportion of news stories does not provide any specific tone. We recoded these stories as having a neutral tone. Unfortunately, the documentation does not provide any information on inter-coder reliability for this variable.

${ }^{12}$ For robustness checks we also differentiated between TV news and newspaper (e.g., Miller and Krosnick, 2000) when coding the proportion of media hits for government actors and the tone variable and we estimated separate models for both outlet types. In general, there are no important differences. However, we find the effects to be somewhat weaker when restricting the analysis to TV news.

${ }^{13}$ An overview of all indicators used can be found in the appendix.
} 
clustered standard errors. ${ }^{14}$ The GSEM accounts for non-independent errors and clusterspecific intercepts identical to a regular random intercept multi-level model. Moreover, we used post-stratification weights on the level of respondents to balance different sampling procedures across the 27 member states and to ensure representativeness of our findings. To capture the priming effect of European issues, we use interaction terms between the issue proximity scale and the visibility, for the valence hypothesis we use a three-way interaction term including issue proximity, visibility and the tone of the EU coverage.

\section{$\underline{\text { Results }}$}

We start with some descriptive statistics for our main variables. Figure 1 summarises the distributions as stacked bar graphs for our dependent variable. The proportions of survey respondents voting for the government in each country are shown as the light-grey section of the bars. There is a large variation between countries in the probability of voting for the governing party, ranging from around 20 per cent in the UK or Hungary and 80 per cent and more in, for example, Belgium, Malta or Italy. There is also huge variation how exit and voice are distributed between countries. Some differences can be explained by country characteristics. For example, compulsory voting leads to a smaller proportion of people abstaining - with the exception of Greece. Looking at Ireland and Slovakia, we see a more or less identical proportion of respondents staying loyal to the government, while the majority of remaining voters in Slovakia chose to abstain and the majority of Irish voters cast a ballot for the opposition. If we make the fair assumption that respondents' characteristics are more or less equally distributed between countries and keeping in mind that differences between electoral systems applied in EP elections are rather moderate, there is a good chance that country-specific characteristics, such as news coverage, are able to account for some of these differences. ${ }^{15}$

\footnotetext{
${ }^{14}$ The GSEM makes it necessary to restrict the number of estimated parameters. In this case, we followed the common approach to restrict the mean of the random intercepts to 1 .

${ }^{15}$ The expectation that country-specific characteristics can account for the variation in the dependent variable is also supported by an intra-class correlation of .16 at the country level.
} 
Figure 1: Exit, Voice and Loyalty in the 2009 EP Elections

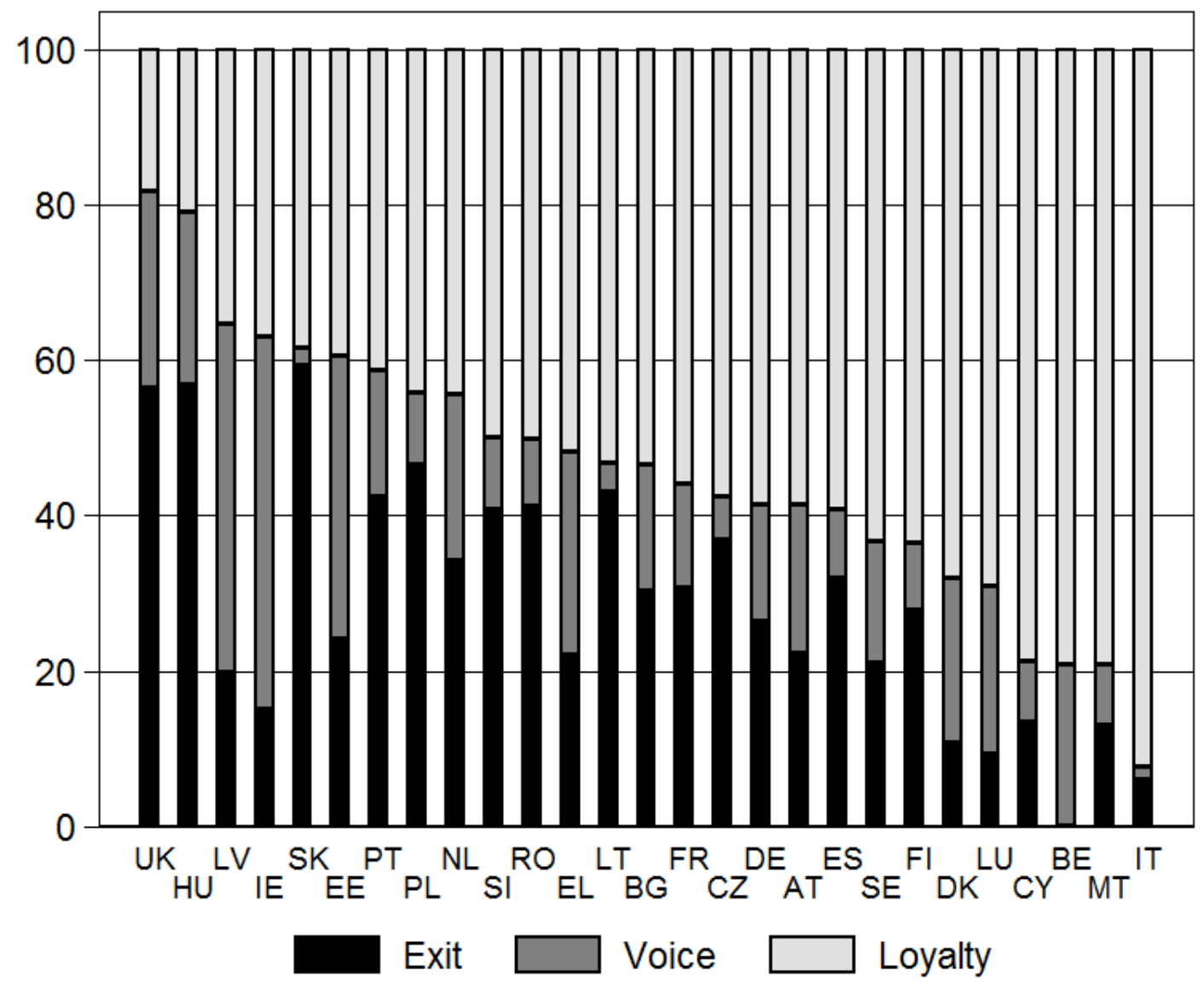

Note: The stacked bar graph presents the share of respondents for each country for each of the three categories of our dependent variable $(\mathrm{N}=9,700)$. Please note that the figure presents the weighted results before listwise deletion took place (see footnote 9). However, there are no relevant differences to the restricted sample after listwise deletion.

Figure 2 presents the governments' visibility as well as the average tone of these media hits in each country. Similar to our dependent variable, there is significant variation between countries. Some governments, for example in Finland or Lithuania, do not feature prominently in the media while others are rather dominant and, hence, highly visible (e.g., the UK, Ireland or Italy). Most of the governments are evaluated negatively in the news. There is no strong correlation between our measure of visibility and the measure of tone: as visibility increases, the tone becomes more negative but the correlation is far from significant even on the 10 per cent level. 
Figure 2: Government Visibility and Tone of Coverage before the 2009 EP Elections

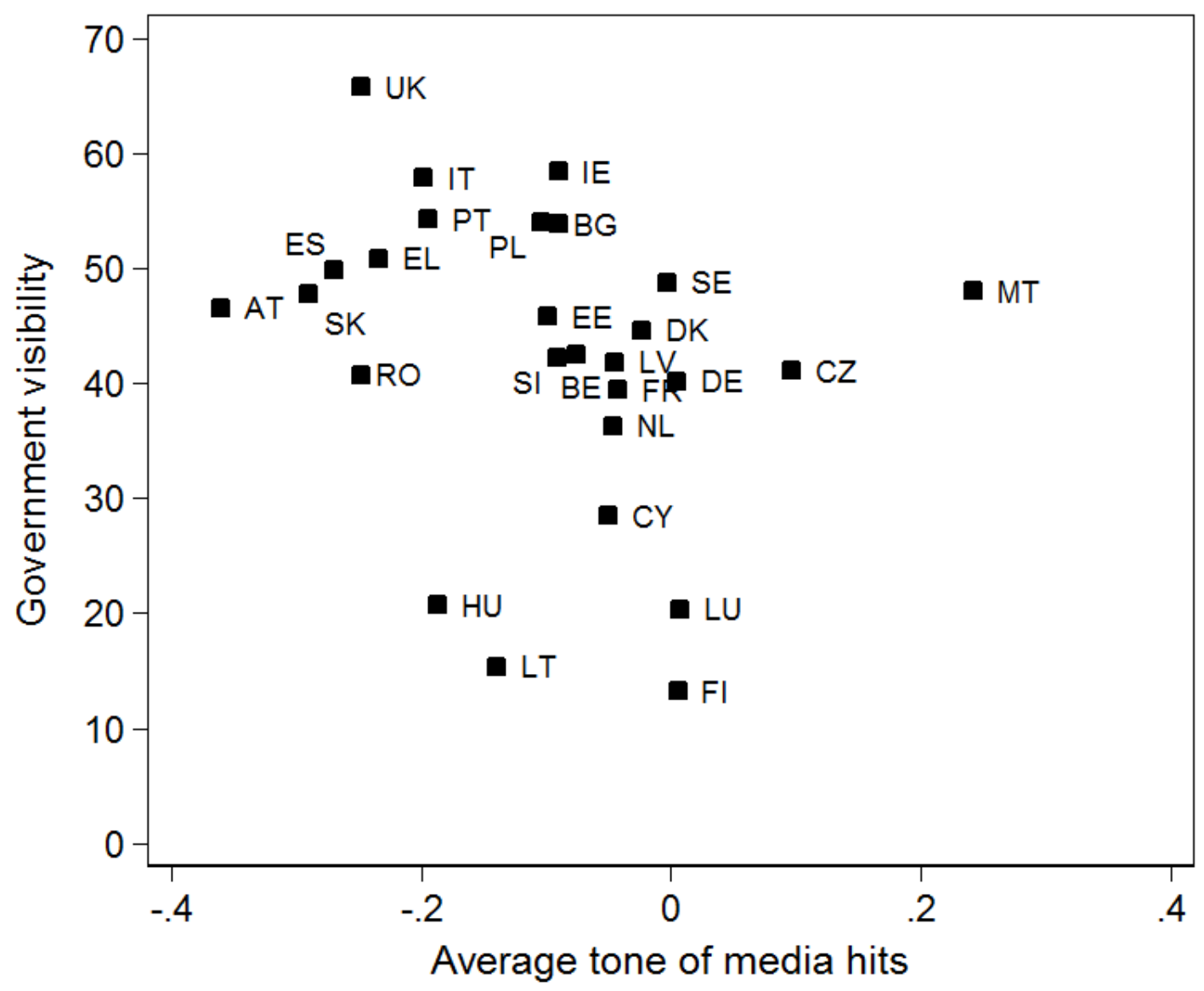

Note: The scatter plots show the country level variation in the visibility of the governing parties in EU news using our constructed variable 'media hits' and the tone of these 'media hits'. Visibility is the proportion of EU news stories that mention governing party actors (government media hits) of all EU news stories. Tone of media hits is the average tone in relation to governing actors in the EU news stories.

Turning to our analytical models, we present 'traditional' regression tables in the appendix. For the purpose of comprehensibility, we chose to highlight our findings with a set of figures that are more appropriate for all hypotheses involving an interaction. However, we start with a look at our control variables including EU issue proximity. As all the following figures are designed in the same way, our explanation of the control variables' results can be taken as a blue print for interpretation. Each figure presents marginal effects of a one-unit change of the independent variable measured as percentage 
points if all other variables in the model are set to their empirical mean. ${ }^{16}$ As we have standardized the variables, we can compare the effect sizes directly (see above).

Figure 3: Exit, voice and loyalty: the effects of control variables ${ }^{17}$

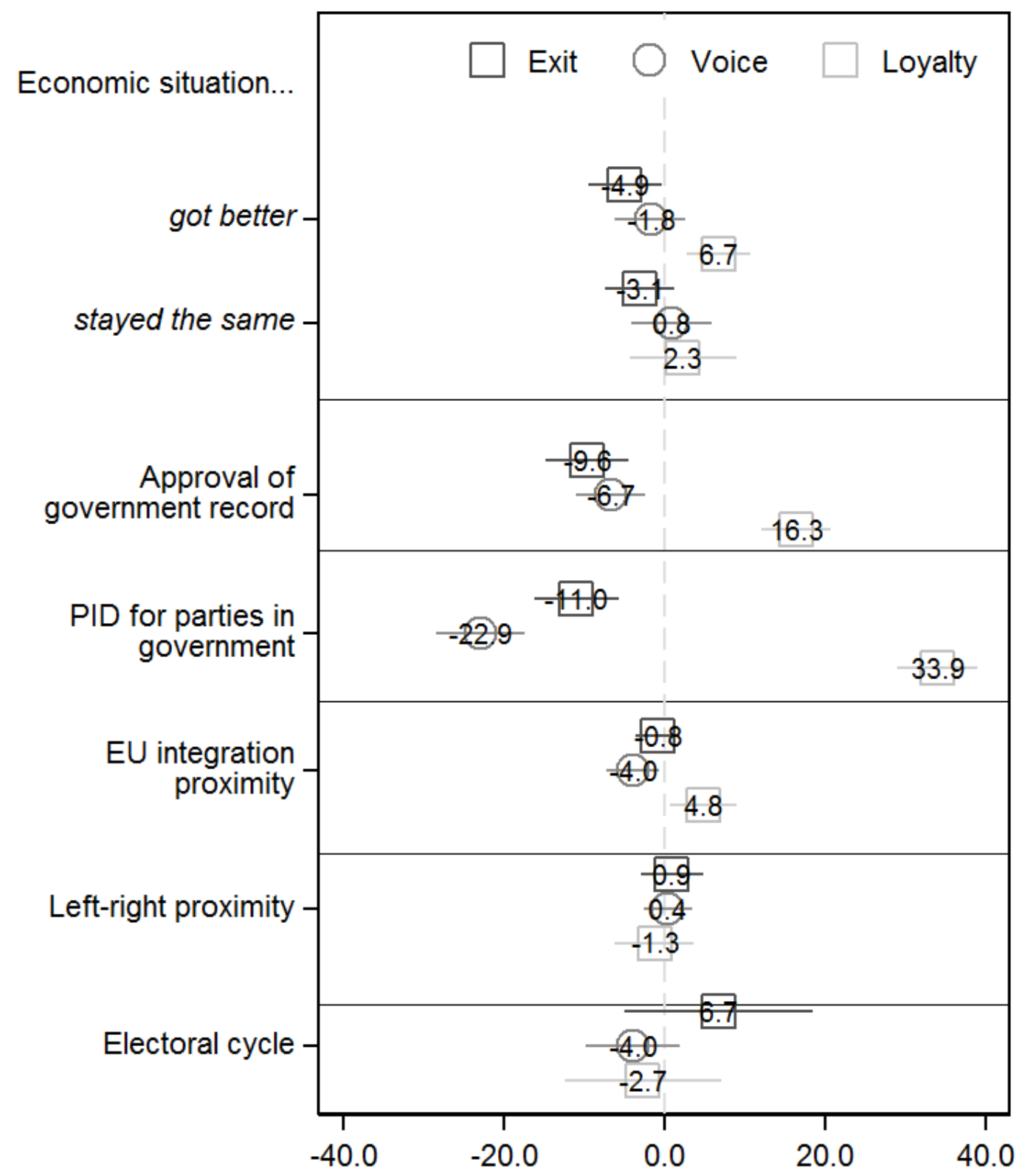

\footnotetext{
${ }^{16}$ Variables located on the country level are set to the mean of all 27 countries and not to the sample mean as this value would be distorted due to unequal sample sizes per country.

${ }^{17}$ We present the results of a baseline model which only includes the controls and EU issue proximity (Model 1 in the Appendix). However, there are no relevant differences resulting from the addition of our variables of primary interest (see Appendix).
} 
Note: Results of a multi-level GSEM with random-intercepts using post-stratification weights. Figures represent marginal effects of a one-unit change of the independent variable measured as percentage points if all other variables in the model are set to their empirical mean. The lines represent the $95 \%$ confidence intervals.

In all remaining figures, we use different colours for each of the three outcomes: the results for exit are depicted in black, those for voice in dark-grey and those for loyalty in light-grey. Looking at the effects from top to bottom, we see that the evaluation of economic developments only shows a significant effect if one compares a positive to a negative evaluation (which is used as the base category). The probability of staying loyal - voting for the government party again in the EP elections - increases by close to seven per cent if the economy is evaluated positively, while the probability of losing voters to abstention decreases. There is no significant effect on 'voice', meaning losing voters to the opposition. Approval of a government's record has the expected effect as it increases the probability to stay loyal while it decreases the probability of exit and voice. The same holds for PID for any of the parties in government. Not too surprisingly, this indicator has the largest effect in our model. Being close to a government's weighted EU integration position results in remaining with the government and not in voting for the opposition. Interestingly, neither the left-right proximity nor the temporal location of the EP election in the national electoral cycle show any significant effect. However, as these variables are of no specific interest in this study, we refrain from speculating on the reasons behind this observation.

Our first step is to examine the direct influence of government party visibility in the news in support for governing parties (H1). To test this unconditional hypothesis, we, in a first step, included all aforementioned independent variables - except the tone variable and the various interaction terms (Model 2 in the Appendix). To cut a long story short, there is no significant effect of visibility on the likelihood to reiterate a voter's support for the governing parties in EP elections. Looking at the results for voiced support for opposition parties or abstention, we do also not see any significant effects. Hence, we have to reject Hypothesis 1: visibility of governing parties in the news media coverage on Europe does not increase the likelihood that voters will stick with their previously endorsed governing party, but it does also not provide any reason to switch or abstain. 
Figure 4: EU issue proximity’s average marginal effect depending on visibility

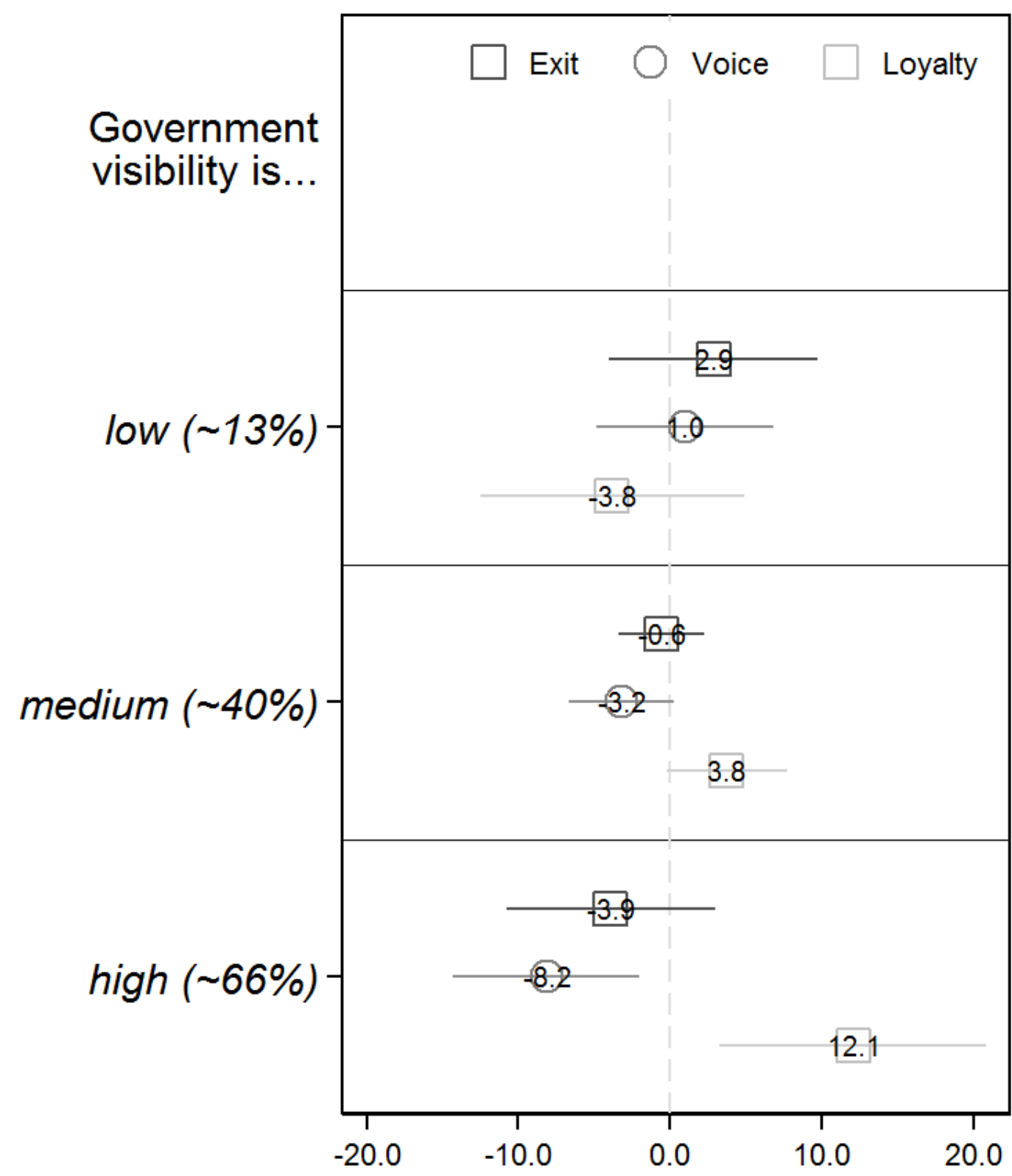

Note: Results of a multi-level GSEM with random-intercepts using post-stratification weights. Figures represent marginal effects of a one-unit change of the independent variable measured as percentage points if all other variables in the model are set to their empirical mean. The lines represent the $95 \%$ confidence intervals.

In a second step, we analysed the first part of Hypothesis 3, namely the direct impact of visibility depending on the tone on vote choice (Model 4 in the Appendix). We have to conclude that visibility is still not affecting vote choice in EP elections: neither for 
government vote nor opposition vote. There is also no effect on the probability to abstain. Hence, government visibility in news media does not directly affect vote choice. We thus have to reject also the first part of Hypothesis $3 .{ }^{18}$ As there is no support for any of our assumptions, we do not present any figures for the sake of saving space.

Turning to our second hypothesis, we included an interaction of EU issue proximity and government visibility into the model (Model 3 in the Appendix). Figure 4 shows the EU issue proximity average marginal effect depending on the level of visibility along the three groups of respondents who voted for the government in the last national election. The effect is larger if visibility is high and there is no difference if visibility is low. With a visibility slightly above 'medium' - 40 percent plus of overall media hits referring to government actors - we get a positive effect for voting for the government and a negative one for switching to the opposition. However, we get a significant difference if the visibility is high. Hypothesis 2 is hence confirmed: EU issue voting is primed by news media's EU coverage and it positively influences vote for the incumbent parties in EP elections where government visibility is high. Meanwhile, vote switching towards opposition parties decreases once EU issue voting is primed. While the electoral disadvantage of incumbents is reduced the more information on the EU is available, the electoral advantage of opposition parties is reduced, as national issues are less important in voters' electoral choices. Priming also reduces the likelihood of exiting though this effect is not statistically significant.

In the last model, we also include tone in our analysis. We used a three-way interaction (EU proximity $\mathrm{x}$ visibility $\mathrm{x}$ tone) to test the second part of Hypothesis 3 (Model 4 in the Appendix). In Figure 5, we show the EU issue proximity's average marginal effect depending on the level of visibility as well as the tone.

While we had to reject the first part of Hypothesis 3 with tone of the coverage having no effect on government's visibility linked to the EU issue, for the second part, we find, as hypothesized, that the priming effect is indeed stronger if the tone is negative. We can thus partly confirm Hypothesis 3. Similar to the general priming effect, this only holds for medium or high visibility. Again, it reduces the electoral disadvantages of

\footnotetext{
${ }^{18}$ This also holds if we only specify a two-way interaction of visibility and tone.
} 
government vote and it decreases voters' likelihood to switch to opposition parties in EP elections, while having no effect on the probability to abstain. In other words, once negative information increases the salience of the European issue to a high level, government parties are less likely to experience vote losses in the sense of respondents giving voice in EP elections.

Figure 5: EU issue proximity's average marginal effect depending on visibility and tone

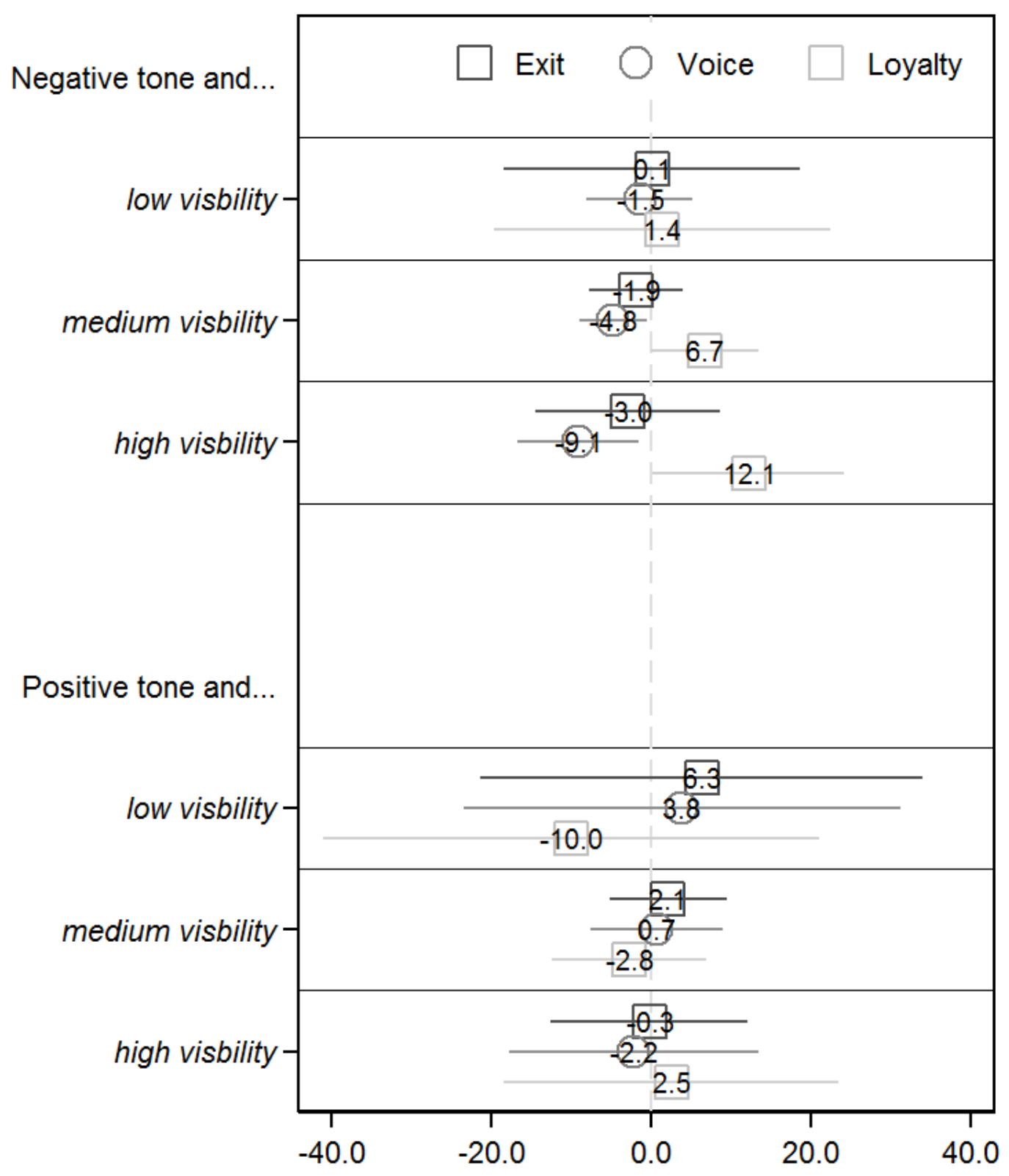


Note: Results of a multi-level GSEM with random-intercepts using post-stratification weights. Figures represent marginal effects of a one-unit change of the independent variable measured as percentage points if all other variables in the model are set to their empirical mean. The lines represent the $95 \%$ confidence intervals.

While we had to reject the first part of Hypothesis 3 with tone of the coverage having no effect on government's visibility linked to the EU issue, for the second part, we find, as hypothesized, that the priming effect is indeed stronger if the tone is negative. We can thus partly confirm Hypothesis 3. Similar to the general priming effect, this only holds for medium or high visibility. Again, it reduces the electoral disadvantages of government vote and it decreases voters' likelihood to switch to opposition parties in EP elections, while having no effect on the probability to abstain. In other words, once negative information increases the salience of the European issue to a high level, government parties are less likely to experience vote losses in the sense of respondents giving voice in EP elections.

In sum, our findings are mixed. There is no indication that visibility alone favours parties in government. Hence, Hypothesis 1 is rejected. There is, however, evidence that visibility has an indirect effect on vote choice in favour of staying loyal to government parties in the EP election as higher visibility linked to the government increases the importance of the EU issue proximity in determining vote choice for the governing party (Hypothesis 2). Negative tone and higher visibility result in a larger effect of EU issue voting and, therefore, we confirm Hypothesis 3 in part as well. As there is also no effect on visibility distinguishing a more negative and a more positive coverage, we also reject Hypothesis 3 in this regard.

\section{$\underline{\text { Discussion and Conclusions }}$}

Since Hooghe and Marks (2009) argued for a post-functionalist view of European integration, scholarly attention has been paid to the conditions under which political parties increase saliency for the issue of Europe strategically in the electoral context. Less focus has been placed on how the news media translate this saliency for voters and the impact it has on shaping preferences. In this paper, we have argued that saliency in the media, as indicated by governing parties being visible in stories about European 
integration, serves to improve the performance of governing parties in these second-order contests. Therefore, we look at the electoral behaviour in the 2009 EP elections of those respondents in the then 27 member states that voted for the government in the last national election.

One of the tenets of the second-order election literature is that EP elections are used to punish governing parties (Hix and Marsh, 2007). This can either be done by abstention (exit) or, more harmful for the national government, by voting for the opposition (voice). However, we argue that increased media coverage highlights the costs of using the EP election to punish governing parties. When European integration is made highly visibly and negatively salient in relation to governing parties, our results suggest that voters increase support for governing parties based on proximity on the issue of Europe. In other words, news media coverage can prime citizens' EU-positions in such a way that they are more likely to be used to determine vote choice (in favour) of governing parties. Defined more broadly, the citizens' calculus of EU issue voting is primed by the (negative and highly visible) news media EU coverage. Using Hirschman's terminology, we see more loyalty to the government and, at the same time, a lower probability to voice discontent by voting for the opposition linked to EU issue voting under such circumstances.

Our analysis points to several important conclusions for studying electoral behaviour in EP elections. In the context of 'Europeanisation' research, we go some way to suggest that the issue of European integration might have the potential to structure electoral behaviour particularly when the EU is a (highly) visible issue in the campaign and this is consistent with previous research (van der Eijk and Franklin, 2004; de Vries, 2007). Indeed, we present evidence that where the issue of Europe is salient in the media coverage, attitudes towards European integration tend to matter more in individual voting behaviour, and the electoral prospects for governing parties improve in EP elections reducing their voters' likelihood to voice dissatisfaction by switching to an opposition party or abstaining altogether. Moreover, we conclude that visibility is important. However, visibility does not translate directly into electoral success but indirectly via political issues, which can be interpreted in both a valence, as well as a positional issue voting logic. 
In line with the theme of this special issue, we show that when there is increased competition, as measured by the appearance of governing parties in EU stories, this can shape party competition. We have focused on governing parties, as one of the major tenets of the second-order theory of EP elections is that these elections adversely influence the performance of governing parties. However, more competition leads to larger coverage of EU issues and through that coverage (and subsequent individual exposure) individual EU positions are indeed primed in the minds of voters as we have demonstrated here.

To sum up, we have explored a new perspective on how the European dimension can diffuse into the national arena and how increased competition can evoke citizens' EU attitudes and policy positions in determining their party choice in EP elections. We uncovered an additional link in the chain that might lead to the awakening of the 'sleeping giant' (van der Eijk and Franklin, 1996): That is the role of the media and its priming effect. 


\section{$\underline{\text { Appendix }}$}

Table A1: Variable descriptions

\begin{tabular}{|c|c|}
\hline Name & Description \\
\hline $\begin{array}{l}\text { Vote Choice in EP } \\
\text { election }\end{array}$ & $\begin{array}{l}\text { Categorical measure; } 2=\text { loyalty to the government party in EP } \\
\text { election; } 1=\text { voiced support for an opposition party in EP elections; } \\
0=\text { exit (abstention) in EP elections. }\end{array}$ \\
\hline Visibility & $\begin{array}{l}\text { Continuous measure; the visibility measure represents available } \\
\text { media hits linked to the government in news stories. It is calculated } \\
\text { as the proportion of all news stories mentioning the EU and the } \\
\text { government or parties in government of all stories on EU issues in } \\
\text { a country. Furthermore, separate measures of the proportion of } \\
\text { media hits for government actors are calculated separately for TV } \\
\text { news and newspapers. }\end{array}$ \\
\hline Tone & $\begin{array}{l}\text { Continuous measure of the average tone of all news stories on the } \\
\text { EU featuring the government. The measure runs from }-2 \text { (very } \\
\text { negative) to } 2 \text { (very positive). }\end{array}$ \\
\hline EU integration proximity & $\begin{array}{l}\text { Continuous measure of absolute proximity of the respondent's } \\
\text { position and government position on European integration. In case } \\
\text { of a coalition government, we calculated the mean position of all } \\
\text { parties in government while using vote shares at the most recent } \\
\text { national election for weighting. The variable runs from } 0 \text { (positions } \\
\text { are antagonistic) to } 10 \text { (identical position). }\end{array}$ \\
\hline Left-right proximity & $\begin{array}{l}\text { Continuous measure of absolute proximity of the respondent's } \\
\text { position and government position on the left-right scale. In case of } \\
\text { a coalition government, we calculated the mean position of all } \\
\text { parties in government while using vote shares at the most recent } \\
\text { national election for weighting. The variable runs from } 0 \text { (positions } \\
\text { are antagonistic) to } 10 \text { (identical position). }\end{array}$ \\
\hline $\begin{array}{l}\text { PID for parties in } \\
\text { government }\end{array}$ & $\begin{array}{l}\text { Binary measure of party identification for any party in government } \\
(1=\text { yes })\end{array}$ \\
\hline $\begin{array}{l}\text { Approval of government } \\
\text { record }\end{array}$ & Binary measure of approval of government record $(1=$ approval $)$ \\
\hline Economic development & $\begin{array}{l}\text { Categorical measure based on the evaluation of sociotropic } \\
\text { economic development in the past } 12 \text { months }(1=\text { got much } \\
\text { better/better; } 2=\text { stayed the same; } 3=\text { got worse/much worse })\end{array}$ \\
\hline Electoral cycle & $\begin{array}{l}\text { Categorical measure; temporal position of the EP election in the } \\
\text { national electoral cycle running from } 0 \text { (right at the middle of the } \\
\text { electoral cycle) to } 1 \text { (EP election takes place on the same day as the } \\
\text { national election). }\end{array}$ \\
\hline
\end{tabular}

Note: Visibility and tone are based on the 2009 EES Media Study (Schuck et al, 2010). The vote shares used to calculate the weighted government positions are taken from various official election resources. All remaining variables are taken from the 2009 EES Voter Study (van Egmond et al, 2010). 
Table A2: Explaining exit, voice and loyalty in the 2009 EP elections

\begin{tabular}{|c|c|c|c|c|c|c|c|c|}
\hline \multirow[t]{2}{*}{$\begin{array}{l}\text { Outcome: EXIT vs } \\
\text { LOYALTY } \\
\text { Respondent level: } \\
N=5,934 \\
\text { Country level: } \\
N=27 \\
\text { Individual level }\end{array}$} & \multicolumn{2}{|c|}{$\begin{array}{c}\text { Model 1: } \\
\text { Baseline model } \\
\text { (without media } \\
\text { variables) }\end{array}$} & \multicolumn{2}{|c|}{$\begin{array}{l}\text { Model 2: } \\
\text { Visibility }\end{array}$} & \multicolumn{2}{|c|}{$\begin{array}{l}\text { Model 3: } \\
\text { Priming }\end{array}$} & \multicolumn{2}{|c|}{$\begin{array}{l}\text { Model 4: } \\
\text { Tone }\end{array}$} \\
\hline & \multicolumn{8}{|c|}{ Individual level } \\
\hline EU integration proximity & $\begin{array}{r}-0.13 \\
(0.11)\end{array}$ & & $\begin{array}{l}-0.13 \\
(0.09)\end{array}$ & & $\begin{array}{r}0.36 \\
(0.34)\end{array}$ & & $\begin{array}{r}0.34 \\
(0.39)\end{array}$ & \\
\hline Left-right proximity & $\begin{array}{r}0.06 \\
(0.12)\end{array}$ & & $\begin{array}{r}0.06 \\
(0.12)\end{array}$ & & $\begin{array}{r}0.06 \\
(0.12)\end{array}$ & & $\begin{array}{r}0.07 \\
(0.12)\end{array}$ & \\
\hline $\begin{array}{l}\text { PID for parties in } \\
\text { government }\end{array}$ & $\begin{array}{r}-1.21 \\
(0.15)\end{array}$ & $* * *$ & $\begin{array}{r}-1.21 \\
(0.15)\end{array}$ & $* * *$ & $\begin{array}{r}-1.21 \\
(0.15)\end{array}$ & $* * *$ & $\begin{array}{r}-1.22 \\
(0.15)\end{array}$ & $* * *$ \\
\hline $\begin{array}{l}\text { Approval of government } \\
\text { record }\end{array}$ & $\begin{array}{r}-0.71 \\
(0.13)\end{array}$ & $* * *$ & $\begin{array}{r}-0.71 \\
(0.12)\end{array}$ & $* * *$ & $\begin{array}{r}-0.71 \\
(0.12)\end{array}$ & $* * *$ & $\begin{array}{r}-0.72 \\
(0.11)\end{array}$ & $* * *$ \\
\hline \multicolumn{9}{|l|}{$\begin{array}{l}\text { Economic development } \\
\text { (base category: got worse) }\end{array}$} \\
\hline stayed the same & $\begin{array}{l}-0.16 \\
(0.14)\end{array}$ & & $\begin{array}{r}-0.17 \\
(0.14)\end{array}$ & & $\begin{array}{r}-0.16 \\
(0.14)\end{array}$ & & $\begin{array}{r}-0.16 \\
(0.14)\end{array}$ & \\
\hline got better & $\begin{array}{r}-0.33 \\
(0.11)\end{array}$ & $* *$ & $\begin{array}{r}-0.33 \\
(0.11)\end{array}$ & $* *$ & $\begin{array}{r}-0.32 \\
(0.11)\end{array}$ & $* *$ & $\begin{array}{r}-0.32 \\
(0.11)\end{array}$ & $* *$ \\
\hline Intercept & $\begin{array}{r}0.37 \\
(0.48) \\
\end{array}$ & & $\begin{array}{r}-0.11 \\
(0.90) \\
\end{array}$ & & $\begin{array}{r}-0.93 \\
(1.28) \\
\end{array}$ & & $\begin{array}{r}-0.41 \\
(0.90) \\
\end{array}$ & \\
\hline \multicolumn{9}{|l|}{ Country level } \\
\hline Electoral Cycle & $\begin{array}{r}0.32 \\
(0.32)\end{array}$ & & $\begin{array}{r}0.33 \\
(0.31)\end{array}$ & & $\begin{array}{r}0.32 \\
(0.31)\end{array}$ & & $\begin{array}{r}0.20 \\
(0.28)\end{array}$ & \\
\hline Visibility & & & $\begin{array}{r}0.29 \\
(0.43)\end{array}$ & & $\begin{array}{r}0.80 \\
(0.67)\end{array}$ & & $\begin{array}{r}0.24 \\
(0.58)\end{array}$ & \\
\hline Tone & & & & & & & $\begin{array}{r}-0.13 \\
(3.22) \\
\end{array}$ & \\
\hline \multicolumn{9}{|l|}{ Interactions } \\
\hline \multicolumn{9}{|l|}{ 2-way interactions } \\
\hline $\begin{array}{l}\text { EU integration proximity } \\
\text { X Visibility }\end{array}$ & & & & & $\begin{array}{r}-0.31 \\
(0.21)\end{array}$ & & $\begin{array}{r}-0.23 \\
(0.28)\end{array}$ & \\
\hline $\begin{array}{l}\text { EU integration proximity } \\
X \text { Tone }\end{array}$ & & & & & & & $\begin{array}{r}0.27 \\
(0.97)\end{array}$ & \\
\hline Visibility X Tone & & & & & & & $\begin{array}{r}-0.50 \\
(1.87)\end{array}$ & \\
\hline \multicolumn{9}{|l|}{ 3-way interaction } \\
\hline $\begin{array}{l}\text { EU integration proximity } \\
\text { X Visibility X Tone }\end{array}$ & & & & & & & $\begin{array}{r}-0.04 \\
(0.59) \\
\end{array}$ & \\
\hline \multicolumn{9}{|l|}{ Random part } \\
\hline Error var., country level & $\begin{array}{r}0.44 \\
(0.16) \\
\end{array}$ & $* *$ & $\begin{array}{r}0.42 \\
(0.16) \\
\end{array}$ & $* *$ & $\begin{array}{r}0.43 \\
(0.16) \\
\end{array}$ & $* *$ & $\begin{array}{r}0.36 \\
(0.15) \\
\end{array}$ & $* *$ \\
\hline
\end{tabular}

Note: All models are generalized structural equation models in a multinomial multi-level random intercept set-up and are estimated with Stata 14's 'svy: gsem' command using post-stratification weights. We present logit coefficients with standard errors in brackets. The mean of the random intercepts is constrained to a value of 1 .

$* \mathrm{p}<.05 ; * * \mathrm{p}<.01 ; * * * \mathrm{p}<.001$ 
Table A2: continued

\begin{tabular}{|c|c|c|c|c|c|c|c|c|}
\hline $\begin{array}{l}\text { Outcome: VOICE vs } \\
\text { LOYALTY } \\
\text { Respondent level: } \\
N=5,934 \\
\text { Country level: } \\
N=27 \\
\end{array}$ & $\begin{array}{r}\text { Model } \\
\text { Baseline } \\
\text { (without } \\
\text { variab }\end{array}$ & $\begin{array}{l}\text { 1: } \\
\text { nodel } \\
\text { nedia } \\
\text { es) }\end{array}$ & $\begin{array}{l}\text { Model 2: } \\
\text { Visibility }\end{array}$ & & $\begin{array}{l}\text { Model } 3 \\
\text { Primin }\end{array}$ & & $\begin{array}{c}\text { Model } 4 \\
\text { Tone }\end{array}$ & \\
\hline \multicolumn{9}{|l|}{ Individual level } \\
\hline EU integration proximity & $\begin{array}{r}-0.37 \\
(0.14)\end{array}$ & $*$ & $\begin{array}{r}-0.37 \\
(0.14)\end{array}$ & $*$ & $\begin{array}{r}0.38 \\
(0.43)\end{array}$ & & $\begin{array}{r}0.29 \\
(0.70)\end{array}$ & \\
\hline Left-right proximity & $\begin{array}{r}0.06 \\
(0.15)\end{array}$ & & $\begin{array}{r}0.05 \\
(0.16)\end{array}$ & & $\begin{array}{r}0.05 \\
(0.16)\end{array}$ & & $\begin{array}{r}0.04 \\
(0.16)\end{array}$ & \\
\hline $\begin{array}{l}\text { PID for parties in } \\
\text { government }\end{array}$ & $\begin{array}{l}-2.10 \\
(0.19)\end{array}$ & $* * *$ & $\begin{array}{l}-2.10 \\
(0.19)\end{array}$ & $* * *$ & $\begin{array}{l}-2.10 \\
(0.19)\end{array}$ & $* * *$ & $\begin{array}{l}-2.09 \\
(0.19)\end{array}$ & $* * *$ \\
\hline $\begin{array}{l}\text { Approval of government } \\
\text { record }\end{array}$ & $\begin{array}{r}0.79 \\
(0.17)\end{array}$ & $* * *$ & $\begin{array}{r}0.78 \\
(0.17)\end{array}$ & $* * *$ & $\begin{array}{r}0.79 \\
(0.16)\end{array}$ & $* * *$ & $\begin{array}{r}0.79 \\
(0.16)\end{array}$ & $* * *$ \\
\hline \multicolumn{9}{|l|}{$\begin{array}{l}\text { Economic development } \\
\text { (base category: got worse) }\end{array}$} \\
\hline stayed the same & $\begin{array}{r}0.00 \\
(0.23)\end{array}$ & & $\begin{array}{r}0.00 \\
(0.23)\end{array}$ & & $\begin{array}{r}0.01 \\
(0.22)\end{array}$ & & $\begin{array}{r}0.00 \\
(0.22)\end{array}$ & \\
\hline got better & $\begin{array}{l}-0.27 \\
(0.17)\end{array}$ & & $\begin{array}{l}-0.27 \\
(0.18)\end{array}$ & & $\begin{array}{l}-0.26 \\
(0.18)\end{array}$ & & $\begin{array}{l}-0.27 \\
(0.17)\end{array}$ & \\
\hline Intercept & $\begin{array}{r}1.18 \\
(0.44)\end{array}$ & $*$ & $\begin{array}{r}0.67 \\
(0.60)\end{array}$ & & $\begin{array}{l}-0.57 \\
(0.99)\end{array}$ & & $\begin{array}{r}-0.12 \\
(1.49)\end{array}$ & \\
\hline \multicolumn{9}{|l|}{ Country level } \\
\hline Electoral Cycle & $\begin{array}{r}-0.22 \\
(0.23)\end{array}$ & & $\begin{array}{r}-0.20 \\
(0.23)\end{array}$ & & $\begin{array}{r}-0.20 \\
(0.23)\end{array}$ & & $\begin{array}{r}-0.25 \\
(0.21)\end{array}$ & \\
\hline Visibility & & & & & $\begin{array}{r}1.06 \\
(0.57)\end{array}$ & & $\begin{array}{r}0.63 \\
(0.92)\end{array}$ & \\
\hline Tone & & & & & & & $\begin{array}{r}0.01 \\
(2.71) \\
\end{array}$ & \\
\hline \multicolumn{9}{|l|}{ Interactions } \\
\hline \multicolumn{9}{|l|}{ 2-way interactions } \\
\hline $\begin{array}{l}\text { EU integration proximity } \\
\text { X Visibility }\end{array}$ & & & & & $\begin{array}{r}-0.46 \\
(0.24)\end{array}$ & & $\begin{array}{r}-0.32 \\
(0.41)\end{array}$ & \\
\hline \multicolumn{3}{|l|}{ EU integration proximity } & & & & & $\begin{array}{r}0.31 \\
(1.03)\end{array}$ & \\
\hline Visibility X Tone & & & & & & & $\begin{array}{r}-0.43 \\
(1.53)\end{array}$ & \\
\hline \multicolumn{9}{|l|}{ 3-way interaction } \\
\hline $\begin{array}{l}\text { EU integration proximity } \\
X \text { Visibility X Tone }\end{array}$ & & & & & & & $\begin{array}{l}-0.01 \\
(0.57) \\
\end{array}$ & \\
\hline \multicolumn{9}{|l|}{ Random part } \\
\hline Error var., country level & $\begin{array}{r}0.44 \\
(0.16) \\
\end{array}$ & $* *$ & $\begin{array}{r}0.42 \\
(0.16) \\
\end{array}$ & $* *$ & $\begin{array}{r}0.43 \\
(0.16) \\
\end{array}$ & $* *$ & $\begin{array}{r}0.36 \\
(0.15) \\
\end{array}$ & $* *$ \\
\hline
\end{tabular}

Note: All models are generalized structural equation models in a multinomial multi-level random intercept set-up and are estimated with Stata 14's 'svy: gsem' command using post-stratification weights. We present logit coefficients with standard errors in brackets. The mean of the random intercepts is constrained to a value of 1 .

$* \mathrm{p}<.05 ; * * \mathrm{p}<.01 ; * * * \mathrm{p}<.001$ 


\section{References}

Adams, J., Ezrow, L. and Somer-Topcu, Z. (2011) Is anybody listening? Evidence that voters do not respond to European parties' policy statements during elections. American Journal of Political Science 55(2): 370-382.

Banducci, S., Giebler, H. and Kritzinger, S. (2015) Knowing Left from Right and More from Less: Information Environments and Knowledge of Party Positions. British Journal of Political Science, DOI: 10.1017/S0007123415000204.

Bawn, K. and Somer-Topcu, Z. (2012). Government versus opposition at the polls: How governing status affects the impact of policy positions. American Journal of Political Science 56(2): 433-446.

Boomgaarden, H.G., Johann, D. and Kritzinger, S. (2016) Voting at National versus European Elections: An Individual Level Test of the Second Order Paradigm. Politics and Governance 4(1): 130-144, DOI: http://dx.doi.org/10.17645/pag.v4i1.472.

Campbell, A. (1960) Surge and Decline: A Study of Electoral Change. Public Opinion Quarterly 24: 397-418.

Dassonneville, R. and Hooghe, M. (2016) The Noise of the Vote Recall Question: The Validity of the Vote Recall Question in Panel Studies in Belgium, Germany, and the Netherlands. International Journal of Public Opinion Research, doi:10.1093/ijpor/edv051.

Delli Carpini, M.X. (2004) Mediating Democratic Engagement: The Positive and Negative Impact of Mass Media on Citizens' Engagement in Political and Civic Life. In: L. L. Kaid (ed.) The Handbook of Political Communication Research. Mahwah, NJ: Lawrence Erlbaum Publishers, pp. 395-434.

De Vreese, C., Banducci, S.A., Semetko, H. and Boomgarden, H. (2006) The News Coverage of the 2004 European Parliamentary Election Campaign in 25 Countries. European Union Politics 7(4): 479-506.

De Vries, C. (2007) Sleeping Giant: Fact or Fairytale? How European Integration Affects National Elections. European Union Politics 8(3): 363-385.

De Vries, C.E., Van der Brug, W., Van Egmond, M.H. and Van der Eijk, C. (2011) Individual and Contextual Variation in EU Issue Voting: The Role of Political Information. Electoral Studies 30(1): 16-28.

Evans, G. (1998) Euroscepticism and Conservative Electoral Support: How an Asset Became a Liability. British Journal of Political Science 28(4): 573-590.

Evans, G. (2002) European Integration, Party Politics and Voting in the 2001 Election. In: L. Bennie, C. Rallings, J. Tonge and P. Webb (eds.) British Elections and Parties Review. London: Frank Cass, pp. 95-110.

Ferrara, F. and Weishaupt, J.T. (2004) Get your Act Together: Party Performance in European Parliament Elections. European Union Politics 5(3): 283-306.

Gabel, M. (2000) European Integration, Voters and National Politics. West European Politics 23(4): 52-72.

Gelman, A. (2008) Scaling regression inputs by dividing by two standard deviations. Statistics in Medicine 27: 2865-2873. 
Giebler, H. (2014) Contextualizing Turnout and Party Choice: Electoral Behaviour on Different Political Levels. In: B. Weßels, H. Rattinger, S. Roßteutscher and R. Schmitt-Beck (eds.) Voters on the Run or on the Move?. Oxford: Oxford University Press, pp. 116-138.

Giebler, H. and Wagner, A. (2015) Contrasting First- and Second-Order Electoral Behaviour: Determinants of Individual Party Choice in European and German Federal Elections. German Politics 24(1): 46-66.

Green-Pedersen, C. (2012) A giant fast asleep? Party incentives and the politicisation of European integration. Political Studies 60(1): 115-130.

Hirschman, A.O. (1970) Exit, Voice, and Loyalty: Response to Decline in Firms, Organizations, and States. Cambridge, MA: Harvard University Press.

Hix, S. and Marsh, M. (2007) Punishment or protest? Understanding European parliament elections. Journal of Politics 69(2): 495-510.

Hix, S. and Marsh, M. (2011) Second-Order Effects Plus Pan-European Political Swings: An Analysis of European Parliament Elections Across Time. Electoral Studies 30(1): 4-15.

Hobolt, S.B., Spoon, J.J. and Tilley, J. (2009) A vote against Europe? Explaining defection at the 1999 and 2004 European Parliament elections. British Journal of Political Science 39(1): 93-115.

Hooghe, L. and Marks, G. (2009) A Postfunctionalist Theory of European Integration: From Permissive Consensus to Constraining Dissensus. British Journal of Political Science 39(1): 1-23.

Iyengar, S. and Kinder, D.R. (1987) News That Matters: Television and American Opinion. Chicago: University of Chicago Press.

Iyengar, S. (1990) Shortcuts to Political Knowledge: Selective Attention and the Accessibility Bias. In: J. Ferejohn and J. Kuklinski (eds.) Information and Democratic Processes. Champaign: University of Illinois Press, pp. 160-185.

Kriesi, H., Grande, E., Lachat, R., Dolezal, M., Bornschier, S. and Frey, T. (2006) Globalization and the Transformation of the National Political Space: Six European Countries Compared'. European Journal of Political Research 45(6): 921-957.

Kriesi, H., Grande, E., Lachat, R., Dolezal, M., Bornschier, S. and Frey, T. (2008) West European Politics in the Age of Globalization. Cambridge: Cambridge University Press.

Krouwel, A. (2004) All Politics Is National, but Policy Is Supra-national: A Decisive Discrepancy. Working Paper of the International Policy Analysis Unit, Friedrich Ebert Stiftung.

Lenz, G.S. (2009) Learning and opinion change, not priming: Reconsidering the priming hypothesis. American Journal of Political Science 53(4): 821-837.

Marcus, G.E., Neuman, W.R. and Mackuen, M. (2000) Affective Intelligence and Political Judgment. Chicago: University of Chicago Press.

Marsh, M. (1998) Testing the second-order election model after four European elections. British Journal of Political Science 28(4): 591-607. 
Mair, P. (2000) The Limited Impact of Europe on National Party Systems. West European Politics 23(4): 27-51.

Miller, J. and Krosnick, J. (2000) News Media Impact on the Ingredients of Presidential Evaluations: Politically Knowledgeable Citizens are Guided by a Trusted Source. American Journal of Political Science 44(2): 295-309.

Mutz, D.C. (1998) Impersonal influence: How perceptions of mass collectives affect political attitudes. Cambridge: Cambridge University Press.

Norpoth, H. (1992) Confidence Regained: Economics, Mrs. Thatcher and the British Voter. Ann Arbor: University of Michigan Press.

Page B.I. and Shapiro R.Y. (1992). The rational public: Fifty years of trends in Americans' policy preferences. Chicago: University of Chicago Press.

Price V. and Tewksbury, D. (1997). News Values and Public Opinion: A Theoretical Account of Media Priming and Framing. Progress in Communication Sciences 13: 172-211.

Reif, K. and Schmitt, H. (1980) Nine Second-Order National Elections: A Conceptual Framework for the Analysis of European Election Results. European Journal of Political Research 8(1): 3-44.

Rohrschneider, R. and Clark, N. (2008) Second-Order Elections versus First-Order Thinking: How Voters Perceive the Representation Process in a Multi-Layered System of Governance. In: C. van der Eijk and H. Schmitt (eds.) The Multilevel Electoral System of the EU. Mannheim: Connex, pp. 137-162.

Scheve, K. (1999) European Economic Integration and Electoral Politics in France and Great Britain. Working Paper, Department of Political Science, Yale University.

Schoenbach, K. and Semetko, H. (1992) Agenda-setting, agenda-reinforcing or agendadeflating: A study of the 1990 German national election. Journalism Quarterly 69(4): 837-846.

Schuck, A., Xezonakis, G., Banducci, S. and de Vreese, C.H. (2010) EES (2009) Media Study Data Advance Release Documentation, 31/03/2010. (www.piredeu.eu)

Schuck, A.R., Xezonakis, G., Elenbaas, M., Banducci, S.A. and De Vreese, C.H. (2011). Party contestation and Europe on the news agenda: The 2009 European Parliamentary Elections. Electoral Studies 30(1): 41-52.

Semetko, H.A. and de Vreese, C.H. (2004) Political campaigning in referendums: Framing the referendum issue. London: Routledge.

Sheafer, T. (2007) How to Evaluate It: The Role of Story-Evaluative Tone in Agenda Setting and Priming'. Journal of Communication 57(1): 21-39.

Tesler, M. (2014) Priming Predispositions and Changing Policy Positions: An Account of When Mass Opinion is Primed or Changed. American Journal of Political Science 59(4): 806-824.

Tillman, E.R. (2004) The European Union at the Ballot Box? European Integration and Voting Behavior in the New Member States. Comparative Political Studies 37(5): 590-610. 
van der Eijk, C. and Franklin, M.N. (eds.) (1996) Choosing Europe? The European Electorate and National Politics in the Face of the Union. Ann Arbor: University of Michigan Press.

van der Eijk, C. and Franklin, M.N. (2004) Potential for Contestation on European Matters at National Elections in Europe. In: G. Marks and M.R. Steenbergen (eds.) European Integration and Political Conflict. Cambridge: Cambridge University Press, pp. 33-50.

van der Eijk, C. and Niemöller, B. (2008) Recall Accuracy and its Determinants. In: K. Arzheimer and J. Evans (eds.) Electoral Behavior. Volume 4: Debates and Methodology. Los Angeles: Sage, pp. 232-280.

van Egmond, M.H., Sapir, E.V., van der Brug, W., Hobolt, S.B., Franklin, M.N. (2010) EES 2009 Voter Study Advance Release Notes. Amsterdam: University of Amsterdam.

Waldahl, R. and Aardal, B. (2000) The Accuracy of Recalled Previous Voting: Evidence from the Norwegian Election Study. Scandinavian Political Studies 23(4): 373-389.

Weber, T. (2011) Exit, Voice, and Cyclicality: A Micrologic of Midterm Effects in European Parliament Elections. American Journal of Political Science 55(4): 906921. 